\title{
Rhombencephalitis associated with isolated Zic4-antibodies in Paraneoplastic cerebellar degeneration: a case report
}

\author{
Philipp A. Loehrer ${ }^{1 *} \mathbb{D}$, Lars Timmermann ${ }^{1}$, Anika Pehl ${ }^{2}$, Corinna I. Bien ${ }^{3}$, Andreas Pfestroff ${ }^{4}$ and David J. Pedrosa ${ }^{1}$
}

\begin{abstract}
Background: Cerebellar degeneration as a consequence of a malignancy is a rare condition most commonly related to the presence of anti-Yo, anti-Hu, and anti-Tr/DNER antibodies. In recent years, several reports have indicated Zincfinger protein 4 (Zic4) antibodies being associated with paraneoplastic cerebellar degeneration (PCD) in patients with small cell lung carcinoma. However, the prevalence and the significance of Zic4-antibodies may be underestimated due to their co-occurrence with more frequent antibodies such as anti-Hu. A literature review of isolated Zic4 mediated paraneoplastic syndromes yielded 14 cases reporting mainly benign clinical courses when treated early.

Case presentation: We present the case of a 67-year-old woman with progressive Zic4 antibody mediated PCD and rhombencephalitis. Immunomodulatory treatment, including intravenous methylprednisolone, plasmaphereses, and intravenous immunoglobulin (IVIG) was administered. Small cell lung cancer (SCLC) was detected, lobectomy performed and cyclophosphamide started. Despite this considerable therapeutic effort, rhombencephalitis led to defiant dysautonomia.

Conclusion: Paraneoplastic syndromes related to isolated Zic4 antibodies are rare and typically show a benign clinical course. Here, we present the first case of a rapidly progressive isolated Zic4 associated PCD and rhombencephalitis. Despite considerable therapeutic efforts, the patient passed away on autonomic dysfunction, highlighting the significance of Zic4 associated disease.
\end{abstract}

Keywords: Paraneoplastic Cerebellar Degeneration, Zic4, Paraneoplastic Syndromes, Autoimmune Encephalitis, Case Report

\section{Background}

Paraneoplastic cerebellar degeneration (PCD) is one of the most frequent paraneoplastic presentations [1]. It is characterized by a subacute onset of symmetrical limb and truncal ataxia, dysarthria, and nystagmus. The symptoms can be preceded by a prodromal phase including fever, headache, nausea, and vomiting, whereby progression to pancerebellar dysfunction occurs within weeks [1]. Symptoms of PCD can antecede tumor diagnosis in more than

* Correspondence: philipp.loehrer@uk-gm.de

'Department of Neurology, University Hospital of Gießen and Marburg, Marburg, Germany

Full list of author information is available at the end of the article
$50 \%$ of the patients depending on the tumor and associated antibody $[2,3]$. Initial brain imaging is usually normal, whereas cerebrospinal fluid (CSF) shows pleocytosis, elevated protein levels, and intrathecal IgG synthesis [4]. Malignancies commonly associated with PCD are small cell lung cancer (SCLC, 33\%), ovarian carcinoma (25\%), and Hodgkin lymphoma (15\%) [4].

The pathogenesis of PCD is attributed to an autoimmune response elicited by the underlying malignancy when proteins restricted to immune privileged neurons are presented by the tumor [4]. In $60 \%$ of the cases, onconeuronal antibodies (targeting intracellular proteins) are identified, although associations with antibodies to cell

(c) The Author(s). 2020 Open Access This article is licensed under a Creative Commons Attribution 4.0 International License, which permits use, sharing, adaptation, distribution and reproduction in any medium or format, as long as you give appropriate credit to the original author(s) and the source, provide a link to the Creative Commons licence, and indicate if changes were made. The images or other third party material in this article are included in the article's Creative Commons licence, unless indicated otherwise in a credit line to the material. If material is not included in the article's Creative Commons licence and your intended use is not permitted by statutory regulation or exceeds the permitted use, you will need to obtain permission directly from the copyright holder. To view a copy of this licence, visit http://creativecommons.org/licenses/by/4.0/ The Creative Commons Public Domain Dedication waiver (http://creativecommons.org/publicdomain/zero/1.0/) applies to the data made available in this article, unless otherwise stated in a credit line to the data. 
surface proteins like voltage-gated calcium channels (VGCC) have been described [4]. Identifying the respective antibody is important, since presence of a wellcharacterized antibody helps to establish the diagnosis of PCD and specific associations between antibody and cancer type exist. Among the most prevalent antibodies in $\mathrm{PCD}$ are anti-Yo, anti-Hu, and anti-Tr/DNER antibodies. AntiYo antibodies (also known as anti-Purkinje cell antibody 1) are directed against Purkinje-cells and typically associate with breast or ovarian cancer as well as a primarily isolated cerebellar syndrome. Anti-Hu antibodies (also known as antineuronal nuclear antibody-type 1, ANNA-1) are attributed to SCLC and the clinical presentation of an encephalomyelitis. Anti-Tr/DNER (delta/notch-like epidermal growth factor-related receptor) antibodies associate with Hodgkin lymphoma and conduct to an isolated cerebellar syndrome.

In the last decades, multiple antibodies have been linked with PCD including Zinc-finger protein 4 (Zic4) antibodies $[4,5]$. Zic4 antibodies are considered onconeuronal antibodies with the zinc finger domain of the intracellular transcription factor Zic4 as the target antigen [6]. Due to the intracellular location of Zic4, antibody associated autoimmunity is potentially $\mathrm{T}$-cell mediated, although exact mechanisms are unknown [5]. Zic4 antibodies hence serve as a biomarker for the syndrome and underlying tumor (see below). The zinc-finger protein of the cerebellum (ZIC) family comprise five transcription factors involved in cerebellar development and maturation [7]. Each factor consists of five Cys2His2 zinc-finger domains and is encoded by one of five ZIC-genes, all of which remained highly conserved throughout evolution [7]. Aberrant ZICgene expression during embryogenesis may entail DandyWalker malformation (Zic1 and Zic4), neural tube defects (Zic2), holoprosencephaly (Zic2), and heterotaxy syndrome (Zic5) [7]. In adults, contrarily, ZIC-protein family alterations primarily manifest as cerebellar dysfunction.

Patients harboring Zic4 antibodies commonly develop PCD and 92\% have SCLC [6]. However, most patients with Zic4 antibodies have concomitant anti-Hu or CRMP5 (collapsin response mediator protein 5) antibodies and present with various additional paraneoplastic syndromes, obscuring the clinical significance of Zic4 antibodies [6, 8]. Isolated Zic4 antibodies, contrarily, appear to be associated with benign paraneoplastic syndromes when treated early. Here, we present the first case of isolated Zic4 antibodies associated with PCD and rhombencephalitis, which subsequently led to fatal dysautonomia, adding important information on how this particular antibody can affect the central nervous system.

\section{Case presentation}

A 67-year-old woman with no relevant past medical or family history was admitted to our emergency department due to progressive staggering vertigo. Ten days prior to admission, the patient had noted unsteadiness of gait and inadequate coordination of her extremities along with truncal instability. In the neurological examination on admission, the patient presented with bilateral dysmetria but especially severe truncal ataxia disabling her to walk. Examination of vertical eye movements revealed upbeat nystagmus, whereas pupillary function, horizontal smooth pursuit, and the vestibulo-ocular reflex were unremarkable. Further neurologic examination was normal, as were the initial laboratory results.

Magnetic resonance imaging (MRI) of the head, including contrast enhanced scans, revealed no pathological findings beyond minor nonspecific vascular white matter hyperintensities on fluid attenuated inversion recovery (FLAIR) sequences. Especially no abnormalities in the brainstem or the cerebellum were present. Cerebrospinal fluid (CSF) showed a pleocytosis $\left(97 / \mathrm{mm}^{3}\right)$ with positive oligoclonal bands. Consecutive serum and CSF analyses were negative for active infectious or systemic autoimmune causes. An immunoblot for intraneuronal antibodies revealed Zic4 antibodies in serum and CSF (coverage: Table 1 and Fig. 1). A combined positron-emission tomography and computed tomography (PET-CT) revealed substantial 18F-fluorodeoxyglucose (FDG) uptake in the right upper pulmonary lobe consistent with lung cancer (Fig. 2.A). Subsequent immunohistochemistry after lobectomy confirmed small cell lung carcinoma (SCLC, Fig. 2.B-E), insofar as that TTF-1 (thyroid transcription factor-1) evidenced a pulmonary origin (Fig. 2.E) and Synaptophysin-staining demonstrated neuroendocrine differentiation (Fig. 2.C). Moreover, a fraction of about $70 \%$ of Ki67-positive cells were indicative of high proliferation rates in this tumor (Fig. 2.D). The patient had previously admitted history of long-term cigarette smoking.

Under the diagnosis of a paraneoplastic cerebellar degeneration (PCD), intravenous methylprednisolone $1000 \mathrm{mg}$ q.d. was administered over five days, followed by five

Table 1 Antibodies assessed in this Case

\begin{tabular}{lll}
\hline Immunoblot & Cell-based assays & Radioimmunoassay \\
\hline Amphiphysin & GAD65 & VGCC \\
CV2/CRMP5 & NMDAR & \\
Ma2/Ta & GABABR & \\
Ri & IgLON5 & \\
Yo & AMPAR2 & \\
Hu & DPPX \\
Recoverin & LGl1 \\
Sox1 & CASPR2 \\
Titin & Glycinereceptor \\
Zic4 & mGluR5 \\
DNER/Tr & mGluR1 \\
\hline
\end{tabular}




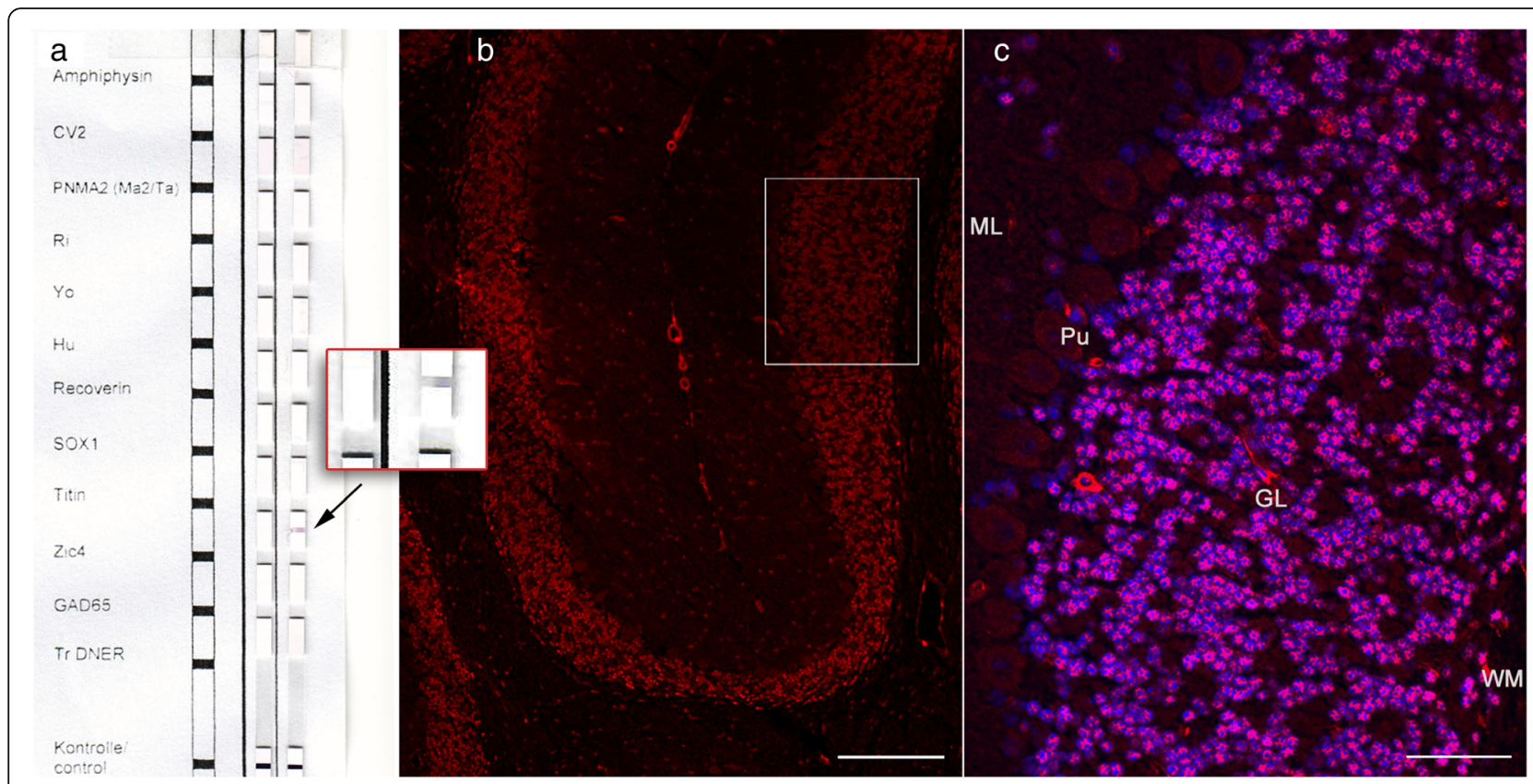

Fig. $1 \mathrm{Imm}$ mnoblot and Immunofluorescence Test on Mouse Cerebellum. Demonstration of Zic4 antibodies in serum (the same results were obtained with cerebrospinal fluid, not shown). a On an immunoblot, 1:100 diluted patient serum produces on the right lane a band with Zic4 only (arrow and insert), not with any other antigen (Euroline DL 1111-1601-4 G, Euroimmun, Lübeck, Germany). The left lane was incubated with a control serum. b Incubation of patient serum, diluted 1:20, with unfixed mouse cerebellum (Euroimmun, Lübeck, Germany). Patient's immunoglobulin G (lgG) binds in a Zic-4-typical pattern to the cerebellar granular cells (cf. Fig. 1 in Bataller et al., 2002 [5]). Bound antibodies are visualized by an anti-human-IgG antibody coupled to a red fluorochrome. Original magnification $\times 100$. Bar: $100 \mu \mathrm{m}$. The area in the rectangle is shown in (C). c Original magnification $\times 400$. Bar: $25 \mu \mathrm{m}$. Zic-4 lgG-antibodies bind to the nuclei of the granular layer and spare the nucleoli. Nuclear counterstaining with Hoechst 33342 1:10.000 in blue. ML= molecular layer; Pu = Purkinje cell layer; GL= granular layer; WM= white matter

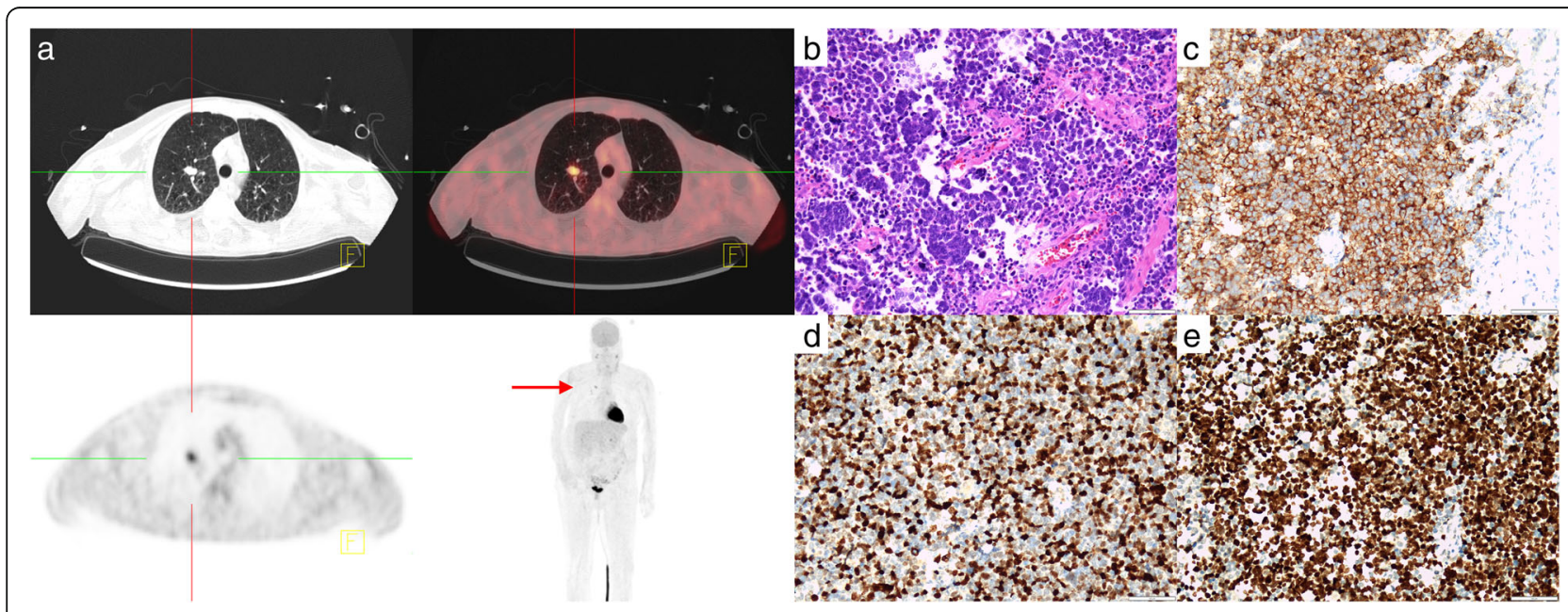

Fig. 2 18F-FDG-PET Findings and SCLC Histology. a FDG-avid lesion in the right upper pulmonary lobe (red arrow) and non-specific uptake in cervical lymph nodes as a consequence of a mild inflammation. b Hematoxylin and eosin (HE) staining (magnification $\times 200$ ), shows the tumor with typical basophil small cells with sparse cytoplasm and irregular nuclei. c Immunohistochemical $(\mathrm{IH})$ staining for Synaptophysin (magnification $\times 200$ ). Tumor tissue stains positive (brown), confirming neuroendocrine differentiation. $\mathbf{d} \| \mathrm{H}$ staining for Ki67 (magnification $\times 200$ ) marks proliferating cells in a tumor. Proliferation rate was up to $70 \%$ in this case. e $\mathbb{H}$ staining for TTF-1 (magnification $\times 200$ ), shows the typical nuclear staining of cells of pulmonary origin 
sessions of plasma exchange. In consequence of increasing respiratory distress and incapacitating opsoclonusmyoclonus syndrome, we had come to an agreement with the patient before to initiate sedation and mechanical ventilation not least because of the pending lobectomy.

After tumor resection, clinical presentation remained unchanged, so that intravenous immunoglobulin (IVIG) were administered for five additional days and cyclophosphamide therapy was started. The patient was discharged to rehabilitation in a cardiopulmonary stable but reduced overall state requiring mechanical ventilation. Regrettably, she deceased six weeks later due to cardiac arrest.

\section{Discussion and conclusions}

This is the first report of isolated Zic4 antibodies associated with rhombencephalitis leading to fatal dysautonomia. In reviewing the literature, a Medline search returned only 14 cases with isolated Zic4 antibodies (Table 2). In the majority of these reports early immunomodulatory treatment conduced to a benign clinical course. Only a single case reported a similarly rapid and clinically severe affection based on coincident spontaneous Creutzfeldt-Jacob disease (CJD) [9]. The authors thereby speculated about autonomic dysfunction and respiratory failure in CJD due to prion deposition in respiratory nuclei. In our patient, however, CJD was ruled out and early immunomodulatory treatment resulted in limited clinical improvement over the entire course. Particularly autonomic dysfunction with cardiac instability and respiratory insufficiency were defiant. In contempt of numerous interdisciplinary tertiary hospital diagnostics and considerable therapeutic efforts, no other pathology was traceable, indicating exclusive paraneoplastic cause. Nevertheless, we acknowledge that presence of other, yet unidentified antibodies cannot be ruled out. In this context, we refer to a recent report describing autoantibodies against Kelch-like-protein-11 (KLHL11ab) causing a paraneoplastic brainstem and cerebellar syndrome resembling the clinical appearance of our patient [13]. Despite an unavailable specific test todate, tissue-based assays were not indicative of the presence of KLHL11-ab in our case.

Irrespective of the divergent clinical course, our case is conforming to previous reports suggesting a link between PCD and Zic4 antibodies. Their presence has most frequently been attributed to SCLC as in our patient $[6,8]$. Nevertheless, a source of uncertainty as for the clinical manifestation related to these antibodies may be the cooccurrence with other antibodies like Anti-Hu- or CRMP5antibodies [6]. Hence, in the first comprehensive case series, Bataller et al. indicated that in 215 patients with paraneoplastic neurologic disorders, 49 showed Zic4 antibodies but only nine patients its exclusive manifestation [6].

In conclusion, we present a rapidly progressive Zic4 antibody related PCD resulting from local SCLC. Despite considerable therapeutic efforts, the patient passed away within few weeks after symptom-onset on autonomic dysfunction. This underlines the significance of isolated Zic4 antibody associated paraneoplastic syndrome and illustrates how this particular autoimmune disorder can affect the central nervous system.

Table 2 Summary of Case Reports of isolated Zic4-Antibodies

\begin{tabular}{|c|c|c|c|c|c|c|}
\hline Author & Age/Sex & $\begin{array}{l}\text { Associated } \\
\text { Tumor }\end{array}$ & $\begin{array}{l}\text { Primary } \\
\text { syndrome at } \\
\text { Diagnosis }\end{array}$ & Symptoms & Treatment & $\overline{\text { Treatment response }}$ \\
\hline Current Study & $67 / F$ & SCLC & $\begin{array}{l}\text { Brainstem, } \\
\text { PCD }\end{array}$ & $\begin{array}{l}\text { Opsoclonus-Myoclonus } \\
\text { Syndrome, Dysautonomia }\end{array}$ & $\begin{array}{l}\text { Methylprednisolone, } \\
\text { Plasmapheresis, IVIG, } \\
\text { Lobectomy, } \\
\text { Cyclophosphamide }\end{array}$ & none \\
\hline Salazar et al. 2018 [9] & $70 / \mathrm{M}$ & None, sCJD & Brainstem, PCD & $\begin{array}{l}\text { Dementia, Ataxia, } \\
\text { Myoclonus, } \\
\text { Dysautonomia }\end{array}$ & Methylprednisolone & none \\
\hline Eye et al. 2018 [10] & $94 / F$ & $\begin{array}{l}\text { DLBCL, } \\
\text { SMM }\end{array}$ & PCD & $\begin{array}{l}\text { Downbeat Nystagmus, } \\
\text { alternating Skew } \\
\text { Deviation, } \\
\text { Gait Ataxia }\end{array}$ & $\begin{array}{l}\text { Chemotherapy, } \\
\text { Rituximab }\end{array}$ & $\begin{array}{l}\text { Improvement but } \\
\text { persisting symptoms }\end{array}$ \\
\hline Aydin et al. 2018 [11] & $40 / F$ & $\begin{array}{l}\text { Ductal breast } \\
\text { cancer }\end{array}$ & SSN & $\begin{array}{l}\text { Pain, Asymmetric } \\
\text { Numbness }\end{array}$ & $\mathrm{n} / \mathrm{a}$ & $\begin{array}{l}\text { Improvement but } \\
\text { persisting symptoms }\end{array}$ \\
\hline Kerasnoudis et al. 2011 [12] & $60 / F$ & $\begin{array}{l}\text { Ovarian } \\
\text { adenocarcinoma }\end{array}$ & PCD & $\begin{array}{l}\text { Progressive Gait Ataxia, } \\
\text { Dysarthria }\end{array}$ & $\begin{array}{l}\text { Methylprednisolone, } \\
\text { Ovariectomy, } \\
\text { Chemotherapy }\end{array}$ & $\begin{array}{l}\text { Complete clinical } \\
\text { remission }\end{array}$ \\
\hline Sabater et al. 2008 [8] & $\mathrm{n} / \mathrm{a}$ & SCLC & PCD & $\mathrm{n} / \mathrm{a}$ & $\mathrm{n} / \mathrm{a}$ & $\mathrm{n} / \mathrm{a}$ \\
\hline Bataller et al. 2004 [6] & $\begin{array}{l}67^{\mathrm{a}} / \\
8: \mathrm{M}, 1: \mathrm{F}\end{array}$ & $\begin{array}{l}\text { 8: SCLC } \\
\text { 1: no tumor }\end{array}$ & $\begin{array}{l}\text { 7: PCD } \\
\text { 1: PCD + LE } \\
\text { 1: LEMS }\end{array}$ & $\begin{array}{l}\text { Cerebellar Ataxia } \\
\text { Cerebellar Ataxia, } \\
\text { Cognitive Dysfunction } \\
\text { Myasthenia }\end{array}$ & $\mathrm{n} / \mathrm{a}$ & $\mathrm{n} / \mathrm{a}$ \\
\hline
\end{tabular}




\section{Abbreviations}

AMPAR2: a-amino-3-hydroxy-5-methyl-4-isoxazolpropionic acid receptor; ANNA-1: antineuronal nuclear antibody-type 1; CASPR2: Contactin-associated protein 2; CRMP5: collapsing response mediator protein 5; CSF: cerebrospinal fluid; CV2/CRMP5: collapsin response mediator protein 5; DLBCL: diffuse large B-cell lymphoma; DNER: Delta/notch-like epidermal growth factor-related receptor; DPPX: Dipeptidyl-Peptidase-like Protein-6; FDG: fluorodeoxyglucose; FLAIR: fluid attenuated inversion recovery; GABABR: $\gamma$-aminobutyric acid-B receptor; GAD65: glutamic acid decarboxylase 65 kDa; GL: granular layer; HE: hematoxylin and eosin; IgG: Immunoglobulin protein, subclass G; IgLON5: immunoglobulin-like cell adhesion molecule 5;

IH: immunohistochemical; IVIG: intravenous immunoglobulin; LE: limbic encephalitis; LEMS: Lambert-Eaton myasthenic syndrome; LGI1: Leucine-rich, glioma inactivated 1; mGluR1/5: metabotropic glutamate receptor 1/5; ML: molecular layer; $\mathrm{mm}^{3}$ : cubic millimeter; NMDAR: N-methyl-D-aspartate receptor; PCD: paraneoplastic cerebellar degeneration; PET-CT: combined positron-emission tomography and computed tomography; Pu: Purkinje cell layer; q.d.: quaque die; Ri: Nova 1 or ANNA-2 (anti-neuron-specific cell nuclear antibodies); (s)CJD: (spontaneous) Creutzfeldt-Jacob disease; SCLC: small cell lung cancer; SMM: smoldering multiple myeloma; Sox1: anti-glia nuclear antibody; SSN: subacute sensory neuropathy; TTF-1: thyroid transcription factor-1; VGCC: voltage-gated calcium channel; Yo: anti-PCA-1 (Purkinje cell antigen 1); ZIC: zinc-finger protein of the cerebellum

\section{Acknowledgements}

The authors thank Christian G. Bien, M.D., Bielefeld and Bad Salzuflen, Germany, for providing Fig. 1 and critical discussion of the manuscript.

\section{Authors' contributions}

PAL conceptualized and designed the study and analyzed and interpreted the patient data. LT conceptualized and designed the study and analyzed and interpreted the patient data. AP1 contributed to the design of the study and analyzed and interpreted the patient data regarding the SCLC histology. CIB contributed to the design of the study and analyzed and interpreted the patient data regarding the immunoblot and immunofluorescence test on mouse cerebellum. AP2 contributed to the design of the study and analyzed and interpreted the patient data regarding the 18F-FDG-PET findings. DJP conceptualized and designed the study and analyzed and interpreted the patient data. The first draft of the manuscript was written by PAL and all authors commented on previous versions of the manuscript. All authors read and approved the final manuscript.

\section{Funding}

The authors declare that they have not received funding to support the presented work.

\section{Availability of data and materials}

Data sharing is not applicable to this article as no datasets were generated or analyzed during the current study.

\section{Ethics approval and consent to participate}

Ethical approval was waived by the local Ethics Committee of University of Marburg in view of the retrospective nature of the short report and all the procedures being performed were part of the routine care.

\section{Consent for publication}

Written informed consent for publication was obtained from nearest to kin (niece) and is available to the journal in German (a translation can be provided on request).

\section{Competing interests}

The authors declare that they have no conflict of interest related to the presented work.

LT reports grants, personal fees and non-financial support from SAPIENS Steering Brain Stimulation, Medtronic, Boston Scientific and St. Jude medical and has received payments from Bayer Healthcare, UCB Schwarz Pharma, and Archimedes Pharma and also honoraria as a speaker on symposia sponsored by Teva Pharma, Lundbeck Pharma, Bracco, Gianni PR, Medas Pharma, UCB Schwarz Pharma, Desitin Pharma, Boehringer Ingelheim, GSK, Eumecom, Orion Pharma, Medtronic, Boston Scientific, Cephalon, Abbott, GE Medical, Archimedes, and Bayer.

\section{Author details}

'Department of Neurology, University Hospital of Gießen and Marburg, Marburg, Germany. ${ }^{2}$ Institute of Pathology, University Hospital of Gießen and Marburg, Marburg, Germany. ${ }^{3}$ Laboratory Krone, Bad Salzuflen, Germany. ${ }^{4}$ Department of Nuclear Medicine, University Hospital of Gießen and Marburg, Marburg, Germany.

Received: 14 February 2020 Accepted: 14 May 2020

Published online: 25 May 2020

\section{References}

1. Dalmau J, Rosenfeld MR. Paraneoplastic syndromes of the CNS. The Lancet Neurology. 2008;7(4):327-40

2. Peterson $K$, Rosenblum MK, Kotanides H, Posner JB. Paraneoplastic cerebellar degeneration. I. a clinical analysis of 55 anti-Yo antibody-positive patients. Neurology. 1992;42(10):1931-7.

3. Graus F, Keime-Guibert F, Rene R, Benyahia B, Ribalta T, Ascaso C, Escaramis G, Delattre JY. Anti-Hu-associated paraneoplastic encephalomyelitis: analysis of 200 patients. Brain : a journal of neurology. 2001;124(Pt 6):1138-48.

4. Hoftberger R, Rosenfeld MR, Dalmau J. Update on neurological paraneoplastic syndromes. Curr Opin Oncol. 2015;27(6):489-95.

5. Bataller L, Wade DF, Fuller GN, Rosenfeld MR, Dalmau J. Cerebellar degeneration and autoimmunity to zinc-finger proteins of the cerebellum. Neurology. 2002;59(12):1985-7.

6. Bataller L, Wade DF, Graus F, Stacey HD, Rosenfeld MR, Dalmau J. Antibodies to Zic4 in paraneoplastic neurologic disorders and small-cell lung cancer. Neurology. 2004;62(5):778-82.

7. Grinberg I, Millen KJ. The ZIC gene family in development and disease. Clin Genet. 2005;67(4):290-6.

8. Sabater L, Bataller L, Suarez-Calvet M, Saiz A, Dalmau J, Graus F. ZIC antibodies in paraneoplastic cerebellar degeneration and small cell lung cancer. J Neuroimmunol. 2008;201-202:163-5.

9. Salazar R. Atypical presentation of probable Creutzfeldt-Jakob disease associated with anti-Zic4 antibody: literature review of neuronal antibodies in Creutzfeldt-Jakob disease. Clin Neurol Neurosurg. 2018;168:72-6.

10. Eye PG, Wang B, Keung ES, Tagg NT. Anti-ZIC4 associated paraneoplastic cerebellar degeneration in a patient with both diffuse large B-cell lymphoma and incidental smoldering multiple myeloma. J Neurol Sci. 2018; 384:36-7.

11. Aydin C, Celik SY, Icoz S, Ulusoy C, Gunduz T, Demir GA, Kurtuncu M, Tuzun E. Prognostic factors in anti-neuronal antibody positive patients. Noro psikiyatri arsivi. 2018;55(2):189-94.

12. Kerasnoudis A. Isolated ZIC4 antibodies in paraneoplastic cerebellar syndrome with an underlying ovarian tumor. Arch Neurol. 2011;68(8):1073.

13. Maudes E, Landa J, Munoz-Lopetegi A, Armangue T, Alba M, Saiz A, Graus F, Dalmau J, Sabater L. Clinical significance of Kelch-like protein 11 antibodies. Neurology(R) neuroimmunology \& neuroinflammation. 2020;7(3).

\section{Publisher's Note}

Springer Nature remains neutral with regard to jurisdictional claims in published maps and institutional affiliations.

Ready to submit your research? Choose BMC and benefit from:

- fast, convenient online submission

- thorough peer review by experienced researchers in your field

- rapid publication on acceptance

- support for research data, including large and complex data types

- gold Open Access which fosters wider collaboration and increased citations

- maximum visibility for your research: over $100 \mathrm{M}$ website views per year

At BMC, research is always in progress.

Learn more biomedcentral.com/submissions 